\title{
GREENHOUSE GAS EMISSION FROM POLISH AGRICULTURE IN YEARS 2007-2016
}

\author{
Paulina Mielcarek, Wojciech Rzeznik \\ Institute of Technology and Life Sciences, Poland \\ p.mielcarek@itp.edu.pl,w.rzeznik@itp.edu.pl
}

\begin{abstract}
One of the important sources of greenhouse gas (GHG) emissions in the world is agriculture. The energy and climate policy of the European Union focuses on reducing greenhouse gas emissions and combating climate change in the non-ETS sectors, including agriculture. In Poland, greenhouse gas emissions from agriculture were $7.7 \%$ of total greenhouse gas (GHG) emissions in 2015. Agriculture represented $30 \%$ of total $\mathrm{CH}_{4}$ emission and $78 \%$ of total $\mathrm{N}_{2} \mathrm{O}$ emission. The implementation of effective activities to reduce GHG emissions from agriculture should be preceded by an analysis of this sector. The aim of the study was to analyse greenhouse gas emissions $\left(\mathrm{CH}_{4}\right.$ and $\left.\mathrm{N}_{2} \mathrm{O}\right)$ from agriculture in Poland and its regional diversification and to identify the main areas of activity in agriculture to reduce GHG emissions. In the years $2007-2016, \mathrm{CH}_{4}$ and $\mathrm{N}_{2} \mathrm{O}$ emissions from agriculture in Poland were at a similar level with neither rise trends nor downward trends. The annual average $\mathrm{CH}_{4}$ emission was $554 \pm 7 \mathrm{Gg}$, and for $\mathrm{N}_{2} \mathrm{O}$ it was $52 \pm 1 \mathrm{Gg}$. The emission of GHG expressed in $\mathrm{CO}_{2}$ equivalent from animal production covered average $53 \%$ of the total $\mathrm{GHG}$ emissions from agriculture, and from crop production it was average $47 \%$. Cattle production had the largest share in emissions from livestock production, and the fertilization from the crop production. The GHG emission from agriculture per square kilometre strongly depends on the region (coefficient of variation $=46.8 \%$ ) and its average value in years 20072016 was $73 \mathrm{Mg} \mathrm{CO}_{2} \mathrm{eq} \cdot \mathrm{km}^{-2}$. The highest were in the Podlaskie Province $\left(143 \mathrm{Mg} \mathrm{CO}_{2} \mathrm{eq} \cdot \mathrm{km}^{-2}\right)$ and Greater Poland $\left(134 \mathrm{Mg} \mathrm{CO}_{2} \mathrm{eq} \cdot \mathrm{km}^{-2}\right)$, where is intensive animal production.
\end{abstract}

Keywords: greenhouse gas emission, agriculture, methane, nitrous oxide.

\section{Introduction}

Global climate change is currently an important problem in global and national politics. In fact, there is some evidence that allows us to state that currently occurring climate change differs from earlier periods of temperature increase in the history of our planet, which was caused only by natural factors. Therefore, it is assumed that global climate change is caused by the long-term impact of human activities on ecosystems. Combustion of large amount of fossil fuels: coal, oil and gas, as well as the limiting of carbon sequestration caused by deforestation, increase emissions and concentrations of carbon dioxide in the atmosphere. One of the important sources of greenhouse gas (GHG) emissions in the world is agriculture. It emits GHG to the atmosphere at almost all stages of production. Agriculture is responsible for $18-51 \%$ of anthropogenic emissions expressed in $\mathrm{CO}_{2}$ equivalent. The population and food demand growth causes the development of agriculture. It leads to an increase in GHG emissions from this sector. At the same time, agriculture is intensifying, what concentrates large emissions of GHG in small areas $[1 ; 2]$.

In 2015, greenhouse gas emissions from agriculture were $7.7 \%$ of total greenhouse gas (GHG) emissions in Poland. The share of agriculture in Polish GHG emissions is relatively small, but emissions of $\mathrm{CH}_{4}$ and $\mathrm{N}_{2} \mathrm{O}$ are of great importance, because they have a much greater potential for the greenhouse effect than $\mathrm{CO}_{2}$. The main source of methane $\left(\mathrm{CH}_{4}\right)$ in agriculture is enteric fermentation from ruminant animals, and its share in the total national emission of this gas was over $26 \%$. On the other hand, nitrous oxide $\left(\mathrm{N}_{2} \mathrm{O}\right)$ is mostly emitted from soils and its emission from agriculture was $78 \%$ of the total national emission of this gas in 2015 [3].

The energy and climate policy of the European Union focuses on reducing greenhouse gas emissions and combating climate change in the non-ETS sectors as well. These sectors are not covered by the Emissions Trading System and they include agriculture, transport, waste, industrial emissions outside the ETS and the municipal and household sector. In 2016, the European Commission published a proposal for a regulation defining new reduction targets for member states by 2030 together with annual emission limits in 2021-2030. The main objectives of the proposed changes are the achievement by the EU in the non-ETS sectors of $30 \%$ emission reduction by 2030 and the implementation of a series of changes and improvements to the non-ETS system. According to the provisions of this regulation, Poland must reduce greenhouse gas emissions in 2030 by $7 \%$ relative to emissions in 2005 [4]. 
The implementation of effective activities to reduce GHG emissions from agriculture should be preceded by an analysis of this sector. It is necessary to identify the main emission areas, emission sources and determine the reduction potential. The aim of the study was to analyse greenhouse gas emissions $\left(\mathrm{CH}_{4}\right.$ and $\left.\mathrm{N}_{2} \mathrm{O}\right)$ from agriculture in Poland, their regional diversification and to identify the main areas of activity in agriculture to reduce GHG emissions.

\section{Materials and methods}

The study analysed the period from 2007 to 2016. Calculations of greenhouse gas emissions from agriculture were made for methane and nitrous oxide. The carbon dioxide emission was neglected, because the emission of this gas from crops and animals is not inventoried in Poland. There were data only about $\mathrm{CO}_{2}$ emission from lime and urea application, but this value is very small, about $0.29 \%$ of total GHG emission in Poland. The $\mathrm{CH}_{4}$ and $\mathrm{N}_{2} \mathrm{O}$ emissions were calculated both for Poland and provinces. The used methodology was in accordance with the guidelines included in the publication of the Intergovernmental Panel on Climate Change (IPCC) [5], using characteristic national data, what allowed to precise results. These data came from the National Centre for Emissions Management (KOBIZE), which is responsible for an annual inventory of air pollution emissions [3; 6]. The calculated emissions of studied gases from major agricultural sources were also expressed in $\mathrm{CO}_{2}$ equivalent using global warming potential factors [7]. This allowed to compare emissions between the regions of the country, the sources of these emissions and groups of animals.

Due to the negligible share in the Polish GHG emissions and in emissions from agriculture, the calculations were made excluding the emissions from the combustion of crop residues, lime and urea application and the production of fur animals. The emissions from drainage/management of organic soils were not estimated for provinces because of the lack of detailed information. Activity data about the population of animals, the consumption of mineral nitrogen fertilizers and sewage sludge for agricultural purposes, crop production came from national statistics prepared by the Central Statistical Office [8; 9].

\section{Results and discussion}

In the years 2007-2016, $\mathrm{CH}_{4}$ and $\mathrm{N}_{2} \mathrm{O}$ emissions from agriculture in Poland were at a similar level with neither rise trends nor downward trends. The $\mathrm{CH}_{4}$ emission ranged from 548 to $566 \mathrm{Gg}$, and its annual average value was $554 \pm 7 \mathrm{Gg}$. For $\mathrm{N}_{2} \mathrm{O}$, this emission oscillated between 50 to $54 \mathrm{Gg}$ with an average of $52 \pm 1 \mathrm{Gg}$. During the whole analysed period, the share of animal production $(53 \%$ on average) in GHG emissions from agriculture was slightly higher than crop production (47\% on average), (Figure 1).

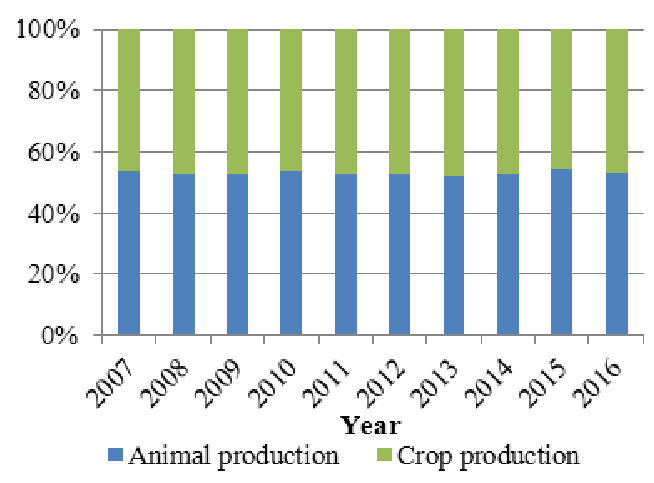

Fig. 1. Share of animal and crop production in GHG emission from Polish agriculture

The dominant source of $\mathrm{CH}_{4}$ emissions from agriculture was enteric fermentation of ruminants, mainly cattle (Figure 2). Its share in total methane emissions from agriculture ranged from 86.2 to $88.6 \%$, on average $87.8 \%$. For $\mathrm{N}_{2} \mathrm{O}$ the main source was managed soils. These emissions result mainly from the use of mineral nitrogen fertilizers, natural and organic fertilization, as well as from crop residues. The $\mathrm{N}_{2} \mathrm{O}$ emission from agricultural soils was between $84.8-87.0 \%$ (average $85.9 \%$ ) of the total emission of this gas from agriculture (Figure 3). 


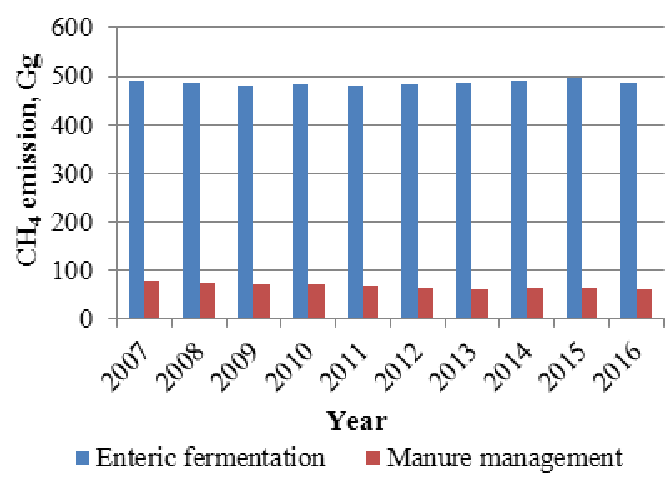

Fig. 2. $\mathrm{CH}_{4}$ emission from Polish agriculture in 2007-2016

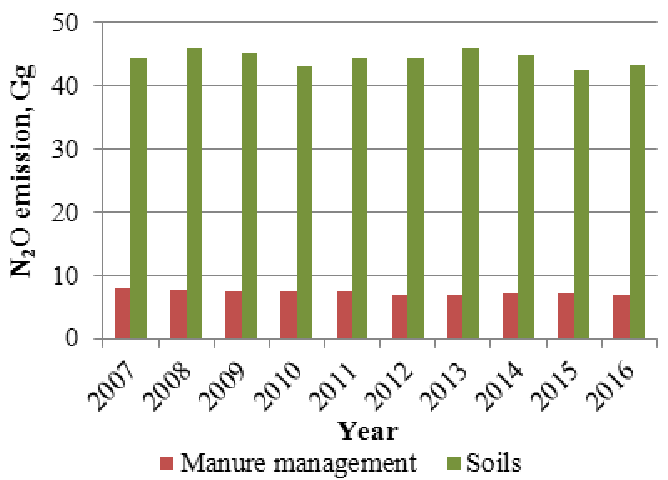

Fig. 3. $\mathbf{N}_{2} \mathrm{O}$ emission from Polish agriculture in 2007-2016

Table 2 shows the GHG emissions from agriculture in division into provinces. The average annual value for $\mathrm{CH}_{4}$ was $30.0 \pm 23.8 \mathrm{Gg}$, and for $\mathrm{N}_{2} \mathrm{O}$ it was equal to $2.68 \pm 1.64 \mathrm{Gg}$. These emissions were strongly regionally differentiated.

Total GHG emissions from Polish agriculture in provinces (average for the years 2007-2016)

\begin{tabular}{|c|c|c|c|}
\hline Province & $\mathbf{C H}_{\mathbf{4}}, \mathbf{G g}$ & $\mathbf{N}_{\mathbf{2}} \mathbf{O}, \mathbf{G g}$ & $\mathbf{G H G}, \mathbf{G g} \mathbf{C O}_{\mathbf{2}}$ eq. \\
\hline Lower Silesia & 10.14 & 2.44 & 955.90 \\
\hline Kuyavia-Pomerania & 43.58 & 3.91 & 2161.11 \\
\hline Lublin & 36.23 & 3.40 & 1839.60 \\
\hline Lubusz & 6.70 & 0.99 & 446.88 \\
\hline Lodzkie & 44.51 & 3.19 & 1966.61 \\
\hline Lesser Poland & 20.40 & 1.18 & 818.93 \\
\hline Masovia & 28.56 & 5.60 & 2314.34 \\
\hline Opole & 11.70 & 1.82 & 807.85 \\
\hline Subcarpathia & 13.00 & 1.00 & 594.80 \\
\hline Podlaskie & 83.97 & 3.24 & 2891.26 \\
\hline Pomerania & 19.17 & 2.13 & 1070.60 \\
\hline Silesia & 11.99 & 1.07 & 591.84 \\
\hline Holy Cross & 16.12 & 1.22 & 730.56 \\
\hline Warmia-Masuria & 38.90 & 2.73 & 1702.98 \\
\hline Greater Poland & 84.49 & 6.92 & 3992.36 \\
\hline West Pomerania & 9.89 & 2.06 & 836.23 \\
\hline
\end{tabular}

The highest $\mathrm{CH}_{4}$ emissions were noted in the Greater Poland, Podlaskie and Lodzkie Provinces, and the smallest in the Lubusz and West Pomerania Provinces. More than half (53\%) of the national emission of this gas from agriculture came from four regions with highly developed animal production: Greater Poland, Podlaskie, Lodzkie and Kuyavia-Pomerania.

In the case of $\mathrm{N}_{2} \mathrm{O}$, the highest emissions were in Greater Poland and Masovia, and the smallest in the Lubusz, Subcarpatia and Silesia Provinces. Almost half (46\%) of the national emission of this gas from agriculture was allocated in four regions: Greater Poland, Masovia, Kuyavia-Pomerania and Lublin Provinces (Table 1).

The total GHG emission from agriculture was calculated by summing the emissions of analysed gases expressed in $\mathrm{CO}_{2}$ equivalent. The largest sources of GHG emission were regions: Greater Poland, Podlaskie, Masovia and Kuyavia-Pomerania, which total emission was $54 \%$ of GHG emissions from agriculture in Poland. In two regions: Greater Poland and Podlaskie with the highest emissions, increase of GHG in last years - 2013-2016 was observed, comparing to the period 20072012. It may result from the continuous development of the agricultural sector, mainly livestock production. 
One of the elements helpful in the evaluation of the impact of agriculture on the environment may be the expression of GHG emission per unit of area, for example: $\mathrm{Mg} \mathrm{CO}_{2} \mathrm{eq} \cdot \mathrm{km}^{-2}$. Using such a form of presenting data about emissions, the scale effect is omitted and it is possible to compare between the regions. For this purpose, the total GHG emissions in $\mathrm{CO}_{2}$ equivalent were expressed per $1 \mathrm{~km}^{2}$ for each province (Figure 4). The average GHG emission per square kilometre from Polish agriculture in 2007-2016 was $73 \mathrm{Mg} \mathrm{CO}$ eq. $\mathrm{km}^{-2}$, and its variation is strongly depending on the region (coefficient of variation $=46.8 \%)$. The highest emissions were in the Podlaskie Province $\left(143 \mathrm{Mg} \mathrm{CO}_{2} \mathrm{eq} \cdot \mathrm{km}^{-2}\right)$, Greater Poland $\left(134 \mathrm{Mg} \mathrm{CO}_{2} \mathrm{eq} \cdot \mathrm{km}^{-2}\right)$, Kuyavia-Pomerania $\left(120 \mathrm{Mg} \mathrm{CO}_{2}\right.$ eq $\left.\cdot \mathrm{km}^{-2}\right)$ and Lodzkie Province $\left(108 \mathrm{Mg} \mathrm{CO}_{2} \mathrm{eq} \cdot \mathrm{km}^{-2}\right)$. These regions are with large animal production, in the first case it is cattle, and in the other - pigs. The smallest emissions of GHG per square kilometre were noted in the Lubusz Province $\left(32 \mathrm{Mg} \mathrm{CO}_{2} \mathrm{eq} \cdot \mathrm{km}^{-2}\right)$, Subcarpatia $\left(33 \mathrm{Mg} \mathrm{CO}_{2} \mathrm{eq} \cdot \mathrm{km}^{-2}\right)$ and West Pomeranian Province $\left(37 \mathrm{Mg} \mathrm{CO}_{2} \mathrm{eq} \cdot \mathrm{km}^{-2}\right)$.

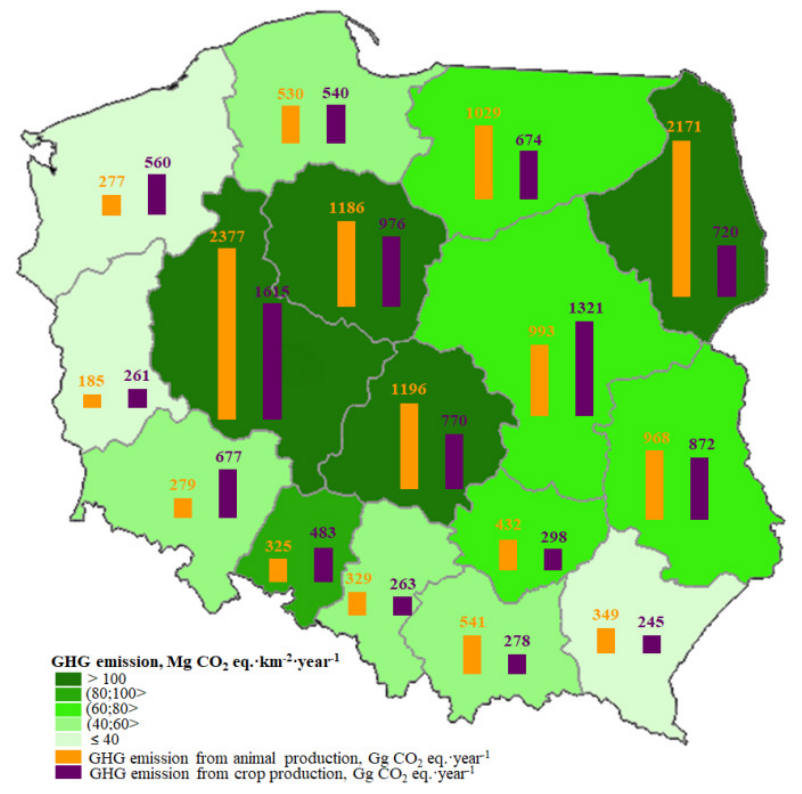

Fig. 4. Diversification of total GHG emissions per $1 \mathbf{k m}^{2}$ from Polish agriculture (average for 2007-2016)

The regions in Poland differed also in the types of production (crop or animal), which were the dominant sources of the GHG emission. The crop production was the main source of GHG emission in the western part of Poland and in Masovia. The western Poland has relatively many commercial family farms and agricultural companies. The large acreage allows to produce only crops with giving the profits at the appropriate level. In contrast, the farms in Masovia are relatively small, and the large share of crop production in total agriculture GHG emission results from the specialization of farms horticulture. In regions, where the average number of kept animals in one farm is much higher than in other regions, the most of GHG emission is from animal production (Figure 4).

Figure 5 presents the share in total GHG emission in provinces of each group of animals: cattle (dairy cows, other cattle), pigs, poultry and other (sheep, horses, goats). In 2007-2016, the highest GHG emissions were caused by cattle production in Poland. The average GHG emission for this group of animals was $12629 \mathrm{Gg} \mathrm{CO}_{2}$ eq.year ${ }^{-1}$ and it was more than five times higher than for other groups of animals together $-2251 \mathrm{Gg} \mathrm{CO}_{2}$ eq.year ${ }^{-1}$. The cattle production is responsible for the majority of GHG emissions from livestock production in each province.

Taking into account the implementation of the European policy of air quality improvement and combating climate change, further reduction of GHG emissions from all economy sectors, including agriculture, will be necessary in the future. There are many technical and technological solutions that could be implemented on farms and effectively reduce GHG emissions, but it requires appropriate financial support. Mitigation activities in agriculture should be carried out primarily in regions with high GHG emission per square kilometre. 


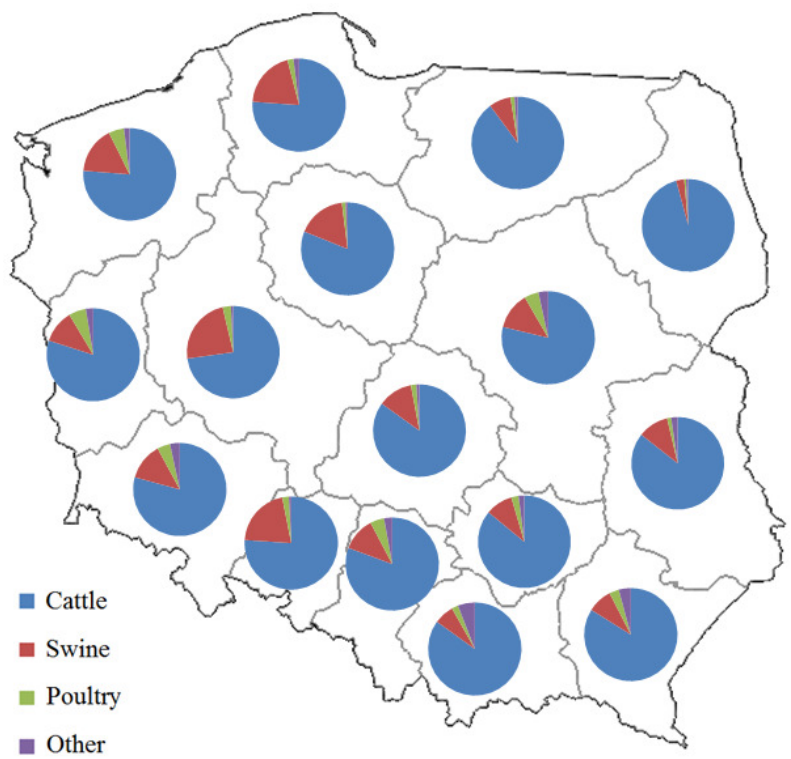

Fig. 5. Share of animal groups in GHG emissions from animal production in Polish agriculture (average for 2007-2016)

Opportunities exist in all segments of agriculture to reduce GHG emission. The most important are changes in management practices, which have potential as effective mitigation measures for the future. In animal production, the practices should focus mainly on the production of dairy and beef cattle. The most important activities seem to be enhancing forage quality and manure treatment for livestock production [10-12]. In the case of crop production, the main direction of GHG emission reduction seems to be improving fertilizer use efficiency and limiting mineral fertilization $[13 ; 14]$.

\section{Conclusions}

1. In the years 2007-2016, $\mathrm{CH}_{4}$ and $\mathrm{N}_{2} \mathrm{O}$ emissions from agriculture in Poland were at a similar level with neither rise trends nor downward trends. The annual average $\mathrm{CH}_{4}$ emission was $554 \pm 7 \mathrm{Gg}$, and for $\mathrm{N}_{2} \mathrm{O}$ it was $52 \pm 1 \mathrm{Gg}$.

2. The emission of GHG expressed in $\mathrm{CO}_{2}$ equivalent from animal production covered on average $53 \%$ of the total GHG emissions from agriculture, and from crop production it was on average $47 \%$. Cattle production had the largest share in emissions from livestock production, and the fertilization from the crop production.

3. The GHG emission from agriculture per square kilometre strongly depends on the region (coefficient of variation-46.8\%) and its average value in the years 2007-2016 was $73 \mathrm{Mg} \mathrm{CO}_{2} \mathrm{eq} \cdot \mathrm{km}^{-2}$. The highest emissions were in the Podlaskie Province $\left(143 \mathrm{Mg} \mathrm{CO}_{2} \mathrm{eq} \cdot \mathrm{km}^{-2}\right)$ and Greater Poland $\left(134 \mathrm{Mg} \mathrm{CO}_{2} \mathrm{eq} \cdot \mathrm{km}^{-2}\right)$, where is intensive animal production.

\section{Acknowledgements}

The work is co-financed by the Ministry of Agriculture and Rural Development and carried under the Multiannual Program for the years 2016-2020 "Technological and environmental projects for innovative, effective and low-emission economy in rural areas".

\section{References}

[1] Kundzewicz Z.W. Zmiany klimatu, ich przyczyny i skutki - obserwacje i projekcje (Climate changes, their reasons and effects - observations and projections). Landform Analysis, vol. 15, 2011, pp. 39-49.

[2] Liang L. , Lal R., Du Z.,. Wu W, Meng F. Estimation of nitrous oxide and methane emission from livestock of urban agriculture in Beijing. Agriculture, Ecosystems and Environment, vol. 170, 2013, pp. 28-35.

[3] Poland's National Inventory Report 2017. Greenhouse Gas Inventory for 1988-2015. Institute of Environmental Protection-National Research Institute. The National Centre for Emissions 
Management. [online] [5.02.2018]. Available at: http://www.kobize.pl/pl/article/krajowainwentaryzacja-emisji/id/384/gazy-cieplarniane.

[4] Regulation of the European Parliament and of the Council on binding annual greenhouse gas emission reductions by Member States from 2021 to 2030 for a resilient Energy Union and to meet commitments under the Paris Agreement and amending Regulation No 525/2013 of the European Parliament and the Council on a mechanism for monitoring and reporting greenhouse gas emissions and other information relevant to climate change. [online] [5.02.2018]. Available at: http://eur-lex.europa.eu/legal-content/EN/TXT/?uri = CELEX:52016PC0482.

[5] 2006 IPCC Guidelines for National Greenhouse Gas Inventories. [online] [5.02.2018]. Available at: https://www.ipcc-nggip.iges.or.jp/public/2006gl/.

[6] A package of tables with data on greenhouse gas emissions in the Common Reporting Format (CRF). It contains detailed data on emissions for the years 1988-2015. [online] [5.02.2018]. Available at: http://www.kobize.pl/pl/article/krajowa-inwentaryzacja-emisji/id/384/gazycieplarniane.

[7] Climate Change 2001: The Scientific Basis. Chapter 6 Radiative Forcing of Climate Change. Intergovernmental Panel on Climate Change. [online] [5.02.2018]. Available at: http://web.archive.org/web/20150222140528/http://www.grida.no/publications/other/ipcc_tar/?src $=/$ climate/ipcc_tar/wg1/248.htm.

[8] GUS - Główny Urząd Statystyczny. (Statistic Poland). (In Polish). [online] [19.12.2017]. Available at: http://stat.gov.pl/.

[9] Produkcja upraw rolnych i ogrodniczych w latach 2007-2016. (Production of agricultural and horticultural crops in 2007-2016). (In Polish). [online] [5.02.2018]. Available at: http://stat.gov.pl/obszary-tematyczne/rolnictwo-lesnictwo/uprawy-rolne-i-ogrodnicze/produkcjaupraw-rolnych-i-ogrodniczych-w-2016-roku,9,15.html.

[10] Yue Q., Xu X., Hillier J., Cheng K., Pan G. Mitigating greenhouse gas emissions in agriculture: From farm production to food consumption. Journal of Cleaner Production, vol. 149, 2017, pp. 1011-1019.

[11] Sejian V., Lai R., Lakritz J., Ezeji T. Measurement and prediction of enteric methane emission. International Journal of Biometeorology, vol. 55, 2011, pp. 1-16.

[12] Berg W., Brunsch R., Pazsiczki I. Greenhouse gas emissions from covered slurry compared with uncovered during storage. Agriculture, Ecosystems and Environment, vol. 112, 2006, pp. 129-134.

[13] Gregorich E.G., Rochette P., VandenBygaart A.J., Angers D.A. Greenhouse gas contributions of agricultural soils and potential mitigation practices in Eastern Canada. Soil \& Tillage Research, vol. 83, 2005, pp. 53-72.

[14] Johnson J.M.-F., Franzluebbers A.J., Lachnicht Weyers S., Reicosky D.C. Agricultural opportunities to mitigate greenhouse gas emissions. Environmental Pollution, vol. 150, 2007, pp. 107-124. 